\title{
The Importance of the 3R Principle of Municipal Solid Waste Management for Achieving Sustainable Development
}

\author{
Bouanini Samiha \\ Resources and Environmental Management \\ International Exchange College, Nanchang University, China \\ E-mail:bs_miha@yahoo.com
}

\section{Doi:10.5901/mjss.2013.v4n3p129}

\begin{abstract}
According to the nature of human life, we find that human produces wastes continually which result pollution. However, human is trying at the same time to find consistent solutions for managing municipal solid waste and to prevent pollution. As well as, human seeks to provide the natural resources for future generation by reducing the use of these natural resources and reuse and recycle it as most as possible. Therefore, in this context, the world can achieve sustainable development. This paper analyzed how the $3 R$ principle (reduce, reuse and recycle) can help to achieve sustainable development. And in order to evaluate and analyze people's behavior and willingness to participate in the $3 R$ principle, this study depends on a survey in a university environment in China. And the results show that although the analyzed sample is educated people but there is a lack in the participation of the $3 R$ principle. As well as there is a lack in environmental knowledge.
\end{abstract}

Keywords: Sustainable Development, Municipal Solid Waste Management, Reduce, Reuse, Recycle, China.

\section{Introduction}

According to the nature of human life, we find that human produces wastes continually which result pollution. And one kind of these wastes is called municipal solid waste which is the general waste collected by municipalities, and it is generated mainly by households, commercial activities and street-sweeping, as well as construction and demolition debris (Martin Medina, 2010, Linda et al, 2003, Olar Zerbock and M.S. Candidate, 2003, and Guilberto and Shigefumi, 2010). Most municipal solid waste is produced in the daily life of local citizens, including dust, titles, paper, plastic, textiles, glass, metal, wood, and residual food (Qi et al, 2006).

However, human is trying at same time to find consistent solutions for managing municipal solid waste and to prevent pollution. Nevertheless, these later can't be prevented and disappeared if the human is still in the earth. Hence, it is our concerns to reduce the pollution by following reduce, reuse, and recycle, which are called the 3R principle.

According to the world commission on environment and development "WCED" (1987), sustainable development is defined as the development that meets the needs of the present without compromising the ability of future generations to meet their own needs. In this context, the $3 R$ principle seeks to provide the natural resources for future generation by reducing the use of these natural resources and reuse and recycle it as most as possible. As well as it reduces pollution by waste minimization and prevent the environment. Therefore, one way among the paths to achieve sustainable development is to promote the management of $3 R$ principle.

This paper will analyze how the $3 R$ principle can help to achieve sustainable development. As well as it will show the importance of managing municipal solid waste according to reuse, reduce and recycle. The reasons behind this study is to increase peoples' awareness about the significance of reducing waste by implementing the $3 \mathrm{R}$ principle as most as possible to provide natural resources for future generation as well as to prevent our environment and society.

\section{Literature Review}

With the economic development in China, the quantity of solid waste increased, and the driving forces behind that are urbanization, urban population growth, and increasing affluence (Dong et al, 2010, and Guilberto and Shigefumi, 2010). However, one of the best ways to reduce the amount of solid waste that must be disposed of is to limit the consumption of raw materials and increase the rate of recovery and reuse of waste materials (Sabir Syed, 2006). 
Currently, the 3R Principles: Reduce, Reuse, Recycle became increasingly implemented in many European countries, USA, Japan, and other developed and developing countries. There are similar studies in China and other countries such as: Chung S. S and Poon (1994) analyzed Hong Kong citizens' attitude towards waste recycling and waste minimization. And they found that Hong Kong people generally support waste recycling and minimization measures. Chung S. A and Poon (1994) examined waste recycling in Hong Kong, and they reached that positive nonintervention policy adopted by the Hong Kong government covered the area of waste recycling and it was a major reason for the sluggish waste recovery rate in Hong Kong. Dan et all (1998) introduced a pilot ecological engineering project for municipal solid waste recycling in Guanghan city of China which aimed to reduce, disinfect, regenerate, industrialize and systematize municipal solid waste through combining hardware, software and mindware. And they showed the ecological and economic benefits of integrated management of municipal solid waste recycling.

Moreover, in 2005, Jasem M. Alhumoud showed the recycling of municipal solid waste in the Gulf co-operation council, and he indicated ways that can help to promote recycling and he provided strategies for developing the most effective recycling marketing program considerations and regional co-ordination options. Martin et al (2006) analyzed householders' attitudes toward recycling in England, and they found that householders are very willing to participate in recycling. Hongpin et al (2009) characterized the recyclable resource recycling system according to a survey in Suzhou city in China, and they reviewed the strategy and policies for promoting and regulating recycling.

In addition, Mohan et al (2011) analyzed environmental benefits of steel recycling in the world. And they presented a discussion on policy issues that could enhance the use of scrap in steel-making. Ming et al (2012) showed the effects of uncontrolled e-waste recycling, and they considered that it can generates persistent toxic substances and releases such compounds into the air, bottom ash, dust, soil, water and seriously adverse effects to local workers and their families.

Furthermore, there are several studies discussed in the $7^{\text {th }}$ international conference on waste management and technology in 2012, about recycling such as: Changjiang et al (2012) talked about resource recycling potentials of urban and rural domestic waste in China. Kun Yue (2012) discussed the scrap car recycling management policies. Miao et al (2012) showed the recycling advancement of used oil in China and over the world. Wenqing et al (2012) showed the recycling and disposal methods for polyurethane foam waste. Xinlai et al (2012) talked about recycling of waste printed circuit boards. Fangfang et al (2012) analyzed recycling of leaded glass. And Lin \& Yang (2012) discussed the e-waste disposal and recycling in China.

From all these previous studies most of them focused only on recycling. However, recycling, reuse and reduce are related and they have same goals and similar benefits on ecology, society and on the economy. Therefore, this paper will analyze the benefits of managing municipal solid waste through $3 R$ principle (reduce, reuse, recycle) to provide natural resources and clean environment for future generation.

\subsection{The 3R Principle (Reduce, Reuse and Recycle)}

Waste management is first to reduce waste generation and separate potential recyclables at source to improve the quality of materials for reuse, including organics for composting or anaerobic digestion. That cannot be reduced should be reused if possible. That cannot be reused or reduced should be recycled, particularly secondary materials such as metal and paper. Wastes that cannot be recycled should be recovered, usually through bacteriological decomposition or should be incinerated or landfilled (World Bank, 2005). And the goals of reduce, reuse, and especially recycle have become the only acceptable ways of disposing of waste (Daniel, 2003). The policy that incorporates waste reduction, reuse, recycling and composting called "zero waste" which means zero disposals and zero warming from waste. Indeed "zero waste" seems to be a difficult but not impossible task. If various options for waste management can be integrated and applied over long period, waste minimization can be addressed effectively and sustainably (N.O. Adedipe et al, 2005).

\subsubsection{Reduce}

The first step in waste management is to try and prevent the generation of waste by reducing at source the waste produced. This is the prevention principal "avoidance of waste" (N.O. Adedipe et. al, 2005, and Bhoj \& Bounsouk, 2005). And one of the best ways to reduce the amount of solid waste that must be disposed of is to limit the consumption of raw materials (Sabir Syed, 2006). Reducing packaging can reduce total waste produced and total resources used (Daniel, 2003). Reducing waste can be also through reducing the use of plastic bags, reducing the use of plastic and paper plates, cups and plastic utensils, and consume more reusable items. 


\subsubsection{Reuse}

Where reducing is not possible, the waste generated should be reused. Reusing items can be by repairing, selling or donating these items to charity and community groups, and therefore this can reduce waste. Reuse is preferable to recycling since the item doesn't need to be reprocessed. In addition to environmental consideration, sensitive reuse schemes can have important social and cultural benefits (UNEP, 2003).

In some developed countries such as Japan, Sweden, Belgium and Denmark, the index of reuse of solid waste is over 90\% (Lino and Ismail, 2012). Moreover, reusing plays an acceptable role in developing countries. In China for example, in order to avoid using plastic bags, the Chinese government has created a policy since 2008, to pay for the plastic bags, and encourage using reusable bags. So, all supermarkets in China sell the plastic bags which pushed people to reduce using it, and provide reusable bags to use instead the plastic bags. Another example in developing countries, refillable glass bottles are still widely used, and families routinely take the empty bottles to grocery stores when they purchase beverages. If someone doesn't bring an empty bottle when purchasing a beverage in a refillable bottle, must pay a deposit equivalent to the cost of the bottle. This encourages the return of reusable bottles, which is in parallel encouraging the reuse principle.

Recently, repairing furniture, bicycles etc..., is often more expensive than buying new products. In many countries reuse centers have been established. These centers aim to break the short product to waste cycle extending the life of the products through repairing them and selling them at a low price. The reuse centers can also be used as means of creating employment for people with problems in entering the job markets or suffering from long term unemployment. In Japan and other industrial countries, "industry clusters" have been planned, where the waste of one industry is the resource of another (N.O. Adedipe et al, 2005).

\subsubsection{Recycle:}

Recycling is taking a product or material at the end of its useful life and turning it into a usable raw material to make another product. It can be promoted by encouraging separation at the source which can be achieved through financial incentives, stimulation, legislation and rising of environmental awareness (Jasem, 2005). The recyclables have to be collected from many sources, including households, business, and construction sites. Then these collected recyclables transported to a materials recovery facility, where they are sorted and processed before being sent to manufacturers. According to European Environment Agency "EEA" report, 2013, many European countries increased the share of municipal waste recycling, and the highest rates are in Austria, with $63 \%$, followed by Germany (62 \%), Belgium (58 \%), the Netherlands (51 \%) and Switzerland (51 \%).

In order to insure the recycling of waste, China has established a number of recycling and disposal waste cooperatives (Miao et al, 2012). Moreover, resource recycling of domestic waste is a major strategic emerging in China, and it is an even more crucial energy saving and environment friendly strategic emerging industry which will continue to grow in the future. And there will be a vast market for second hand materials in China (Chang Jiang et al, 2012).

However, recycling is a manufacturing process, and therefore it too has environmental impact but these impacts are less than landfill and incineration, as well as they are less than producing new products with virgin materials (Daniel, 2003).

The convention that resulted in Kyoto protocol realized in Japan, in 1997, established that industrializes countries must reduce their emissions during the period 2008- 2012. And the developing countries had a big potential for reducing their emissions. China, for example had the biggest annual reductions of emissions with $46 \%$ (Lino and Ismail, 2012).

\subsection{The Importance of the $3 R$ Principle}

The most importantly is that $3 R$ principle helps us toward sustainable living. Making people think about the impact of their consumption and production of waste can help to encourage us to make lifestyle decisions to reduce the waste we create and reduce the impact on the environment.

Reduce, reuse and recycle help to save natural resources for the future (Sabir Syed, 2006, Mohan et al, 2011, Lino and Ismail, 2012).

In addition, as more items are reduced or reused and recycled, the amount of waste that needs to go to the landfill or incinerator is also reduced, in this way we can save the costs of landfill and incineration as well as we can save landfill space (UNEP, 2003, Lino and Ismail, 2012). 
Furthermore, recycling and reuse create more job opportunities, as recycling continue to grow, more workers will be needed to collect, sort, and process recyclables. And reuse centers can also be used as means of creating job opportunities (Ankit, et al, 2005, Kun Yue, 2012).

Applying 3R principle creates less air pollution and reduces climate emissions, such as $\mathrm{CO}_{2}$ and green house gas emissions (UNEP, 2003, Conrad and Jan, 2010, Mohan et al, 2011, Lino and Ismail, 2012).

Moreover, recycling saves energy (Conrad and Jan, 2010, Kun Yue, 2012, Sifang et al, 2012), and it reduces water pollution and water consumption (Lino and Ismail, 2012). There are countries that do not have their own natural resources but they can import waste material, such as paper as raw material for their manufacturing industries.

\section{Data and Methodology}

A quantitative methodology is followed in this research in order to evaluate and analyze people's behavior and willingness to participate in reduce, reuse and recycle. This study used a survey in a university environment in China. And the questionnaire is composed of several questions concerning reduce, reuse and recycle. It has addressed randomly 250 residents in the university, but only 194 of them were available.

In addition, this survey has chosen university's residents because most of them representing students and few teachers and other staff. And the target is to analyze the extent of the knowledge of educated people about 3R principle. Moreover, there was a rear goal which is to revive the idea of the $3 R$ principle for the residents and move their ideas toward the use of reduce, reuse, and recycle. As well as it is targeted to create a 3R principle's culture.

Furthermore, in order to analyze the results, this study used SPSS statistics 20 software. And it used descriptive statistics.

\section{Results Analysis}

After collecting information from the survey, we found that there were answers from 194 residents, 100 of them were males, and 94 of them were females. And there were $68 \%$ of them Chinese, and $32 \%$ of them were foreigners. And the figure "1" bellow shows the number of individuals according to the gender and nationality.

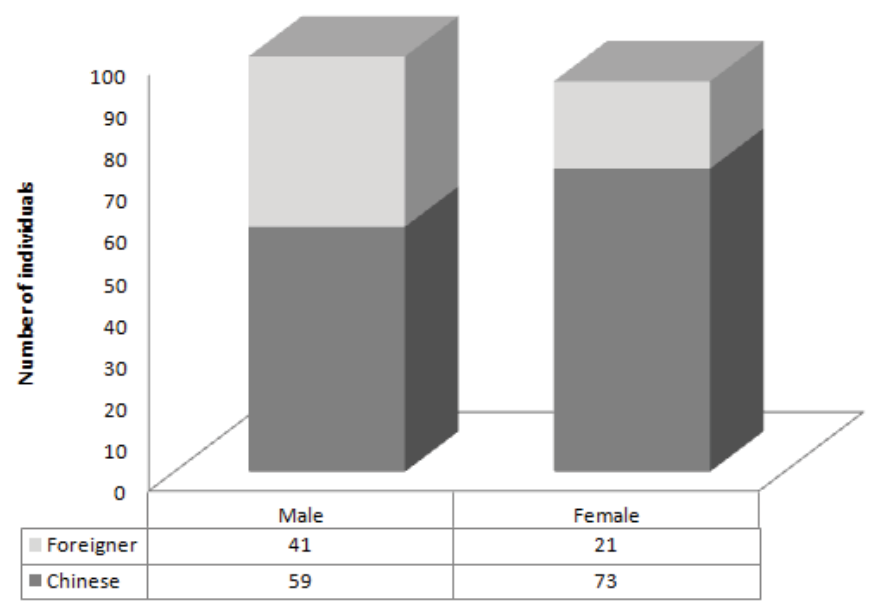

Figure 1: Individuals according to the gender and nationality

The following figure "2" shows the residents' participation in reduce, reuse and recycle. 


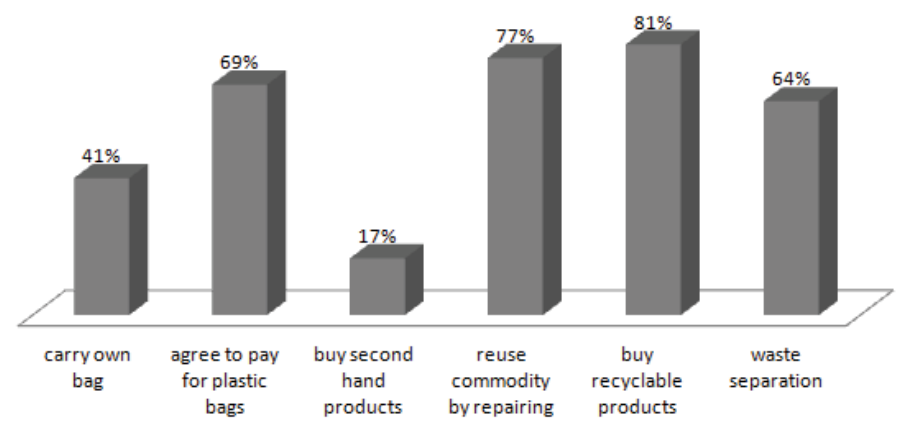

Figure 2: Residents' Participation in Reduce, Reuse and Recycle

According to the results, $41 \%$ of the residents carry their own bags when they go to the market, $42 \%$ of them are males and $58 \%$ are females. These percentages show that females help more in reducing the use of plastic bags. And most of the residents agree to pay for the plastic bags when they purchase from supermarkets. This acceptance shows that most of them are aware about the negative effects of the plastic bags and they know about the importance of reducing the use of plastic bags. However, there is still lack in the participation of waste reduction.

In addition, there are a very small percentage of individuals, who buy second hand products, $\quad 64 \%$ of them are foreigners and $36 \%$ of them are Chinese. But, at same times most residents -especially the Chinese people- prefer to repair the commodity and use it again. So they use items as much as possible. But there is still lack in participation of reusing second hand products.

The results show also that people are very willing to buy recyclable products because $81 \%$ of residents agree to buy recyclable products where $59 \%$ of them think that these are good products and $41 \%$ of them think that are average products. Moreover, $64 \%$ of the residents contribute to waste separation, and thus can facilitate the process of recycling for businesses.

Most of people think that environmental education program is useful for society and the environment, however, only $64.9 \%$ of the residents who have watched before an environmental education program about the ways for environmental protection.

Table 1: Residents who Watched an Environmental Education Program

\begin{tabular}{|cc|c|c|c|c|}
\hline & & Frequency & Percent & Valid Percent & Cumulative Percent \\
\hline \multirow{3}{*}{ Valid } & yes & 126 & 64.9 & 64.9 & 64.9 \\
& no & 68 & 35.1 & 35.1 & 100.0 \\
& Total & 194 & 100.0 & 100.0 & \\
\hline
\end{tabular}

We have proposed in this survey whether the government makes a policy to pay a tax for the waste generated by each person every year, but most of the residents didn't agree (see figure " 3 " bellow which shows the percentage of agreement and disagreement about tax for waste generated every year), and they proposed that government should make incentives instead of enforcing tax. If there are more incentives, so there will be more participation in waste reduction, reuse and waste recycling.

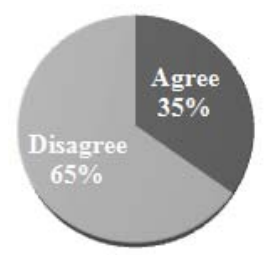

Figure 3: Different Views toward the Policy of Paying Tax for Waste Generated Every Year 


\section{Conclusion and Recommendation}

The results show that although the analyzed sample is educated people but there is a lack in the participation of the $3 R$ principle. As well as there is a lack in environmental knowledge. These results push us to formalize some conclusions and recommendations as follow:

The $3 \mathrm{R}$ principle is a great way to protect our environment and stimulate our economy. However there is a need for environmental education which is very important by providing students with important life lessons through engaging on $3 \mathrm{R}$ principle that promote responsible and sustainable environmental behaviors. And educate the whole community about the benefits of waste reduction, reuse and recycling.

Other than being more aware and cautious of all our actions, we should also seek to integrate recycling practices as well as reducing and reusing habits into our everyday lives and our day-to-day activities so that it becomes a norm rather than an option.

Local governments should make more incentives to increase 3R principle's participation by providing householders with financial incentives which can increase participation and recycling rates and by supporting the concept of people paying less is they recycle more.

We can help to realize a closed-loop for recycling if everyone brings the waste (e.g. paper, plastic, glass) to recycling centers. Then this waste will be sold to factories, where they use that waste to make new products and people will buy the new products and use then recycle them and the whole loop starts again.

We should make use of items as much as possible and encourage the consumption of second hand products.

Reduce, reuse and recycle are also a form of patriotism, because we are helping our country to save money and reduce our dependence on other countries for raw materials.

Every single human being living on this planet has a part to play in reducing, reusing and recycling, as well as in protecting this precious world, and making it greener, less toxic and more inhabitable.

\section{Reference}

Ankit Agarwal, Ashish Singhmar, Mukul Kulshrestha, Atul K. Mittal, 2005, Municipal Solid Waste Recycling and Associated Markets in Delhi, Resources Conservation and Recycling, Vol: 44, No: 1, PP: 73-90.

Bhoj Raj Khanal and Bounsouk Souksavath, 2005, Environmental Management Measures and Current Practices in Solid Waste Management: A Case Study From Vientiane, Lao People's Democratic Republic, Greater Mekong Subregion Academic and Research Network "GMSARN", Vol: 4, No: 1, PP. 5-19

Chang Jiang Yang, Mengdi Yang, and Qian Yu, 2012, An Analytical Study on the Resource Recycling Potentials of Urban and Rural Domestic Waste in China, The 7th International Conference on Waste Management and Technology, Procedia Environmental Sciences, Vol: 16, PP: 25- 33.

Chung S. A, and Poon C. S, 1994, Waste Recycling in Hong Kong, Waste Management and Research, Vol: 12, No: 1, PP: $21-32$.

Chung S. S, and Poon C. S, 1994, Hong Kong Citizens' Attitude towards Waste Recycling and Waste Minimization Measures, Resources, Conservation and Recycling, Vol: 10, No: 4, PP: 377- 400.

Conrad Luttropp, Jan Johanson, 2010, Improved Recycling with Life Cycle Information Tagged to the Product, Journal of Cleaner Production, Vol: 18, No: 4, PP: 346- 354

Dan Hu, Rusong Wang, Jingsong Yan, Cheng Xu, Yinbing Wang, 1998, A Pilot Ecological Engineering Project for Municipal Solid Waste Reduction, Disinfection, Regeneration and Industrialization in Guanghan City, China, Ecological Engineering, Vol: 11, No: 1-4, PP: 129- 138.

Daniel K. Benjamin, 2003, Eight Great Myths of Recycling, Jane S. Shaw (Ed), PERC Policy Series, Issue Number Ps-28, the Center for Free Market Environmentalism, P: 1- 26, Available Online On PERC's Website: www.perc.org

Dong Qing Zhang, Soon Keat Tan, and Rechard M. Gersberg, 2010, Municipal Solid Waste Management in China: Status, Problems and Challenges, Journal of Environmental Management, Vol: 91, PP: 1623-1633.

European Environment Agency, 2013, Managing Municipal Solid Waste- A Review of Achievements in 32 European Countries, Report No: 2, Luxembourg Publications Office of the European Union, printed in Denmark, P: 13

Fangfang Xie, Lili Liu, and Jinhui Li, 2012, Recycling of Leaded Glass: Scrap Cathode Ray Glass and Fluorescent Lamp Glass, the 7th International Conference on Waste Management and Technology, Procedia Environmental Sciences, Vol: 16, PP: $585-589$.

Guilberto Borongan and Shigefumi Okumura, 2010, Municipal Waste Management Report: Status-Quo and Issues in South East and East Asian Countries, Copyright VAIT/UNEP Regional Resource Center for Asia and the Pacific, United Nations Environment Programme, Thailand, PP.1-43.

Hong Pin Mo, Zongguo Wen, and Jining Chen, 2009, China's Recyclable Resources Recycling System and Policy: A Case Study in Suzhou, Resources, Conservation and Recycling, Vol: 53, No: 7, PP: 409- 419.

Jasem M. Alhumoud, 2005, Municipal Solid Waste Recycling in the Gulf Co-Operation Council, Resources, Conservation and Recycling, Vol: 45, No: 2, PP: 142- 158. 
Kun Yue, 2012, Comparative Analysis of Scrap Car Recycling Management Policies, The 7th International Conference on Waste Management and Technology, Procedia Environmental Sciences, Vol: 16, PP: 44- 50

Lin Wei, Yang Sheng Liu, 2012, Present Status Of E-Waste Disposal and Recycling in China, the 7th International Conference on Waste Management and Technology, Procedia Environmental Sciences, Vol: 16, PP: 506- 514.

Linda Tietjen, Débora Bossemeyer, and Noel Mclntosh, 2003, Infection Prevention Guidelines for Healthcare Facilities with Limited Resources, Eight: Waste Management, JHPIEGO, USA, PP: 105-118.

Lino F. A. M, and Ismail K. A. R, 2012, Analysis of Potential of Municipal Solid Waste in Brazil, Environmental Development, Vol: 4, PP: 105- 113

Martin Medina, 2010, Solid Waste, Poverty and the Environment in Developing Country Cities, Challenges and Opportunities, Working Paper No. 2010/23, Copyright of United Nations University and World Institute For Development Economics Research, PP: 1-13.

Martin M, Williams I. D, and Clark M, 2006, Social, Cultural and Structural Influences on Household Waste Recycling, Vol: 48, No: 4, PP: 357- 395.

Miao Yu, Hong Zhi Ma, and Qun Hui Wang, 2012, Research and Recycling Advancement of Used Oil in China and all over the World, the 7th International Conference on Waste Management and Technology, Procedia Environmental Sciences, Vol: 16, PP: 239243.

Ming Man, Ravi Naidu, and Ming H. Wang, 2012, Persistent Toxic Substances Released from Uncontrolled E-Waste Recycling and Actions for the Future, Science of the Total Environment, Doi: 10-1016 J.SCITOTENV. 2012.07.017

Mohan Yellishetty, Gavin M. Mudd, P. G. Ranjith, and A. Tharumarajah, 2011, Environmental Life Cycle Comparisons of Steel Production and Recycling: Sustainability Issues, Problems and Prospects, Environmental Science \& Policy, Vol: 14, No: 6, PP: 650- 663.

N.O. Adedipe, M.K.C. Sridhar, and Joe Baker, 2005, Ecosystems and Human Well-Being Policy Responses, Chapter 10: Waste Management, Processing and Detoxification, Millennium Ecosystem Assessment Series, Edition 1, Island Press, PP.313-334

Olar Zerbock, and M.S. Candidate, 2003, Urban Solid Waste Management: Waste Reduction in Developing Nations, Requirements of CE 5993 Field Engineering in the Developing World, School of Forest Resources \& Environmental Science, Michigan Technological University, PP: 2-21.

Qi fei Huang, Qi Wang, Lu Dong, Beidou Xi, and Binyan Zhou, 2006, the Current Situation of Solid Waste Management in China, Springer-Verlag, Journal Mater Cycles Waste Management, Vol: 8, PP: 63-69.

Sabir Syed, 2006, Solid and Liquid Waste Management, Emirates Journal for Engineering Research, Vol: 11, No: 2, PP: $19-36$.

Sifang Kong, Hui Liu, Hui Zeng, Yangsheng Liu, 2012, The Status and Progress of Resource Utilization Technology of E-Waste Pollution in China, the 7th International Conference on Waste Management and Technology, Procedia Environmental Sciences, vol: 16, PP: 515- 521.

United Nations Environment Programme "UNEP", 2003, A Manual for Water and Waste Management: What the Tourism Industry Can Do to Improve its Performance, United Nations Publication, (ISBN: 92-807-2343-x), PP: 3-13.

Wenqing Yang, Qingyin Dong, Shili Liu, Henghua Xie, Lili Liu, and Jinhui Li, 2012, Recycling and Disposal Methods for Polyurethane Foam Wastes, the 7th International Conference on Waste Management and Technology, Procedia Environmental Sciences, vol: 16, PP: 167- 175.

World Bank, 2005, Waste Management in China: Issues and Recommendations, East Asia Infrastructure Department Working Paper N: 9, PP: 7-60

World Commission on Environmental Development "WCED", 1987, our Common Future, Oxford University Press, Oxford

Xianlai Zeng, Lixia Zheng, Henghua Xie, Bin Lu, Ka Ixia, Kuoming Chao, Weidong Li, Jianxin Yang, Szuyin Lin, and Linhui Li, 2012, Current Status and Future Perspective of Waste Printed Circuit Boards Recycling, the 7th International Conference on Waste Management and Technology, Procedia Environmental Sciences, Vol: 16, PP: $590-597$. 
